\title{
Architectural and Planning Art in the Cultivation of the Living Environment
}

\author{
Igor Bondarenko \\ Scientific Research Institute of Theory and History of Architecture and Urban Planning \\ Central Institute for Research and Design of the Ministry of Construction and Housing and Communal Services of the Russian \\ Federation \\ Moscow, Russia \\ igor.bondarenko.54@mail.ru
}

\begin{abstract}
The article analyzes primary meanings of architectural activity as the art of natural territories organization and reveals the philosophical and religious foundations of a building culture. It then discusses evolutionary and revolutionary historical processes of the development and degradation of the skill of architects and planners. The crisis in the functioning of the profession of architect and urban planner of modern times is being acknowledged. The necessity of returning to the traditions of cultivation of architecture with the aim of returning it its high status in the system of the arts on the new basis is being formulated.
\end{abstract}

Keywords-architecture; art; urban planning; culture; environment; chaos and organization

\section{INTRODUCTION}

Since old days, there was a communal culture that defined typical features of life, including cultivation of natural areas, planning, and development of traditional settlements [1]. This culture was based on a sustained social consensus, on a firm belief in the truth of the sacred commandments and models, given in revelations to the great ancestors, heroes and the first teachers of humanity [2]. Contemporary history is characterized by other issues, particularly, the collapse of the authorities and the rapid growth of self-reflection. This results in encouragement of creative subjectivism and relaxedness, which could even lead to nihilistic permissiveness. It is also true that, in contrast to this, it is required to put all creative activity on a rational scientific basis and to subordinate it to unifying regulation [3]. However, as a result, we have an impression that a struggle without rules is going on and brings resentment and disappointment, and benefits only to those who are stronger and less bound by principles. In my opinion, both sides today lack moderation, mutual respect, generosity, and hence culture in the lofty meaning of the word.

\section{CHAOS AND ORGANIZATION}

It seems that we should look for a way out of the situation in the revival based on reasonable and viable hierarchical relations both in the professional community and nationwide [4]. I expect reproaches for supporting anti- democratic tendencies. My answer is this: the pyramid actually exists today, and not without reason, since without it the system disintegrates. We are unsatisfied, in fact, only by the effectiveness of this pyramid, and that is why we have to apply "manual control" every now and then.

Now and again, we hear the revolutionary calls to put an end to subordination. Today the trend is to substitute vertical hierarchical systems with horizontal networks in the name of universal equality [5]. However, the networks are not as harmless as they might seem. There is always someone who controls and misuses them; they threaten the freedom of individuals who lose their independence in them, as if in a trap.

In fact, people need not to eliminate the hierarchy, not to get rid of superiors, but to have considerate and responsible higher-ups. A discredited hierarchy needs to be rebuilt and adjusted, avoiding the signs of totalitarian voluntarism and taking care of the legitimate involvement of all strata of the population in its complex activities. We should not set vertical and horizontal connections against each other; we need both of them to function coherently and effectively.

Such formulation of the question mitigates the tension in the attitude towards the problem of delimiting the spheres of responsibility and functions of different departments (in our case, the Ministry of Culture, the Ministry of Construction, the Ministry of Economic Development, the Ministry of Natural Resources and others). Unambiguity in this matter is not always useful. Overlapping of spheres of responsibility is natural and even fundamentally important as many problems solved on borderlines and in neutral zones that do not belong to anyone and, therefore, are common responsibility. This provides more opportunities to build a reasonable system of goal-setting that permeates and unifies all spheres, no matter how different they are.

Culture and art cannot be given to a single specialized ministry, since they are present (more precisely, should be present) in any field of human activity - in economy, politics, engineering, and agriculture - everywhere... [6] It is important to realize that each profession can give birth to a high, medium or low culture. What is essential is the gradation of the quality of professional activity, although it is 
often overlooked, while the uniqueness of specific professions is emphasized.

The cultures of the upper class, the middle class, the lower class, the culture of the outcasts are often viewed as something completely different. This renders the concept of culture meaningless. It would be better, if, distinguishing different types of behavior and lifestyles, the culture would be considered a common pivot, piercing them from top to bottom and giving the opportunity to create a uniform assessment scale.

What has been said about culture and art can be attributed to science as well. On the one hand, specialization decomposes science into a multitude of isolated and mutually unintelligible fields. On the other hand, all these directions represent different facets of a single whole - the Science, in which there are different registers: high, medium, and low, from fundamental to applied. State academies of sciences were created on the basis of this hierarchical model. Their mission was to grow star scientists and to nurture elite communities. Today, this is not an appropriate discourse, and academies are only supposed to help ministries to solve problems in their specific fields of responsibility. This is a threat to academies, as this way they might lose their identity. Once, the decisive turn of the Academy of Construction and Architecture of the USSR to the pressing applied problems led to a situation where its functions were duplicated by the Gosstroy (State Committee for Construction), which later resulted in conflicts and closing of the academy due to its uselessness [7].

This means that cultural policy cannot and should not be departmental. It is known that the rise of the Soviet architecture of the 1930s-1950s happened due to the special attention of the government. During his struggle against immoderacy, Nikita Khrushchev left architecture without the attention of the Department of Culture of the Central Committee of the Communist Party of the Soviet Union. It was entrusted only to the Department of Construction and the Gosstroy, with all the consequences that followed.

\section{Cult MeAning OF ARCHITECTURE}

How to bring back glory to architecture and to return it to the domain of high culture and great art? The hint, in my opinion, is present in the very word culture, in its root, carrying the meaning of special concentration of spiritual and creative efforts in the name of pursuing the ideal. We fear the deceitfulness of ideals and the concentration of power in the hands that are unworthy of it. But this does not mean that we have to abandon the original idea of cultivating selected values, leading to the formation of sustained cultural traditions that inspire communities and bring them together.

From ancient times, architecture had a religious meaning [8]. This implied not only sanctuaries, but also residential, public, and defensive structures. Building process was a sacrament, because it could not have happened without God's help and favor. This is openly stated in the famous Psalm: "Unless the Lord builds the house, its builders labor uselessly" (Ps. 126.1). Hence the traditional adherence to authoritative models with miraculous archetypes behind them. It was impossible to violate the precepts of the ancestors, although the emotional freshness, the unique vitality of each new act of creation was also required. Therefore, it makes sense to talk about the cultivation of architecture, as well as other arts and crafts, for centuries and millennia retaining a religious foundation.

The secularization of culture, the expansion of the sphere of the profane, which has dissociated itself from the shrunk sphere of the sacral, all this led to an unprecedented liberation of architectural and engineering creativity [9]. The results of the progress are amazing and delightful. At the same time, they introduce confusion into the habitual way of thinking and the conventional worldview [10]. As a reaction to this, the idealization of the past and nostalgia arise. Such a reaction does not strengthen, but weakens our positions. It is better to unite and harmonize the concepts of culture and civilization, and not to oppose them to each other, as Spengler used to do [11].

This brings us to the following conclusion: it is not particular historical architectural techniques and styles that need to be revived, they are gone along with their time (albeit not completely), but the common age-old principle of cultivating architecture and urban art as an essential means of protecting and sustaining the individual and society. No wonder the buildings were meant to imitate the universe that was created as a stronghold of the divine life in opposition to the deadening chaos [12]. This means that, first of all, it is necessary to go back to the most attentive, responsible, and serious attitude towards architecture and urban planning. We have to realize that the very life of people, many generations of them, directly depends on this.

The 20th century saw many attempts to transform society through architecture and urban planning. All of them deepened the alienation of people from the architecture that was imposed on them in the pursuit of political and economic goals [13]. We need an entirely different vector of architecture for the sake of true life. It is necessary to cultivate a serious, honest, noble architectural and urbanplanning science, and not cover up our ignorant voluntarism with a pseudo-scientific façade. In project creativity, it is necessary to encourage not an empty originality, but a genuine talent for achieving expressiveness and perfection.

It is necessary to make efforts to refute the conviction that architecture is created solely for convenience and satisfaction of human necessities. In fact, appearing on Earth, it inevitably becomes a part of the entire inhabited world. Too often, it turns out to be inappropriate, aggressive and harmful to this world. Too often, we are ashamed of violated nature and the decaying cultural heritage.

I hope that a different time is approaching, which will impose stricter requirements on architecture and urban planning in the area of biosphere compatibility of the Earth [14], as it used to be in the ancient times. There is no talk about the revival of ancient cults, but they should be replaced with new genuinely cultural values. There are some signs of the liberation of the spiritual, idealistic origins from the dominance of the clichés of pragmatic materialism. We clearly do not pay enough attention to contemplating and 
creating ideals, both social and architectural. The high spiritual culture should take care of this. The specific ways and milestones towards the future are unknown ("inscrutable"). What we need is not so much forecasts and programs as a constant, persistent focus on the improvement, pacification and enculturation of what already exists and what is yet to appear. It is necessary to stop damaging the Earth, we need to develop, improve, and cultivate it, as it was bequeathed. Cultivate with the help of the cult of architecture and urban art, as it used to be in the era of antiquity.

I have to make a remark that, no matter how beautiful the architecture of antiquity was, we should not copy or replicate it. Nor should we, admiring, for instance, the cities of the Russian Empire, continue to follow the approaches to urban planning that were applied back then and practice deliberate cultivation in the European manner of that time. If true ancient Russian cities had existed today, then we would, of course, try to preserve, restore and turn them into museums for scientific, educational, and touristic purposes, like it is done in modern Europe.

I would also like to say that today architecture has achieved the right to be different, to be diverse in types and styles. There are few chances to find fundamentally new ways of its development and, moreover, to achieve their universal recognition. In such a situation, the efforts of architects are doomed to go not in breadth, but in depth, towards a detailed study of well-known techniques, which means, right in the direction of cultivating of professional skills.

\section{CONCLUSION}

Architecture has the potential of assuming the leading role in beautification, and ideally - in adornment of the Earth, since it is natural for architecture not to follow the arbitrariness of the construction industry, but to direct the industry. It is unknown, what architecture will be in the future, but it will certainly flourish when we stop thinking of it as an expensive superstructure over a flawed and always imperfect material basis. After all, architecture does not begin with the procurement of building materials, but with the emergence of ideas and development of design. That is why it was considered the mother of the arts. That is what we need to cultivate in it.

This requires certain efforts, creative will, and aimed policy, because there is no aimless and weak-willed selfperfection. Only deconstruction can happen by itself. The policy, however, should be truly cultured - prudent, intellectual, and elevated. One can argue that there is no point in such fantasies. I object: this happened before and happens now in reality despite the most unfavorable circumstances. Otherwise, everything would have perished long ago. It is necessary to realize, appreciate and increase good spiritual impulses and at least modest successes on this thorny, but rightful path. This is the idea of the architectural and planning art in cultivating the living environment.

\section{REFERENCES}

[1] N.I. Tolstoy, Slavic faith // Slavic mythology: Encyclopedia. Moscow, 1995, pp. 15-26.

[2] A.K. Bayburin, The ritual in traditional culture. Structural-semantic analysis of East Slavic ceremonies. St. Petersburg: «Nauka», 1993. pp $5-16$

[3] G.V. Esaulov, The spheres of influence of architecture // Architecture and the social world / edited by. I.A. Dobritsyna. Moscow: Progresstraditciia, 2012. pp. 193-195.

[4] I.A. Bondarenko, The architecture and social hierarchy. Past, present, possible future // Architecture and the social world / edited by. I.A. Dobritsyna. Moscow: Progress-traditciya, 2012. pp. 75-82.

[5] V.L. Kaganskiy, Postmodernism. Cultural landscape. Russia // Project Russia. 2010. Dwelling vol. I. pp. 197-200.

[6] I.A. Bondarenko, Topical problems of Economics of cultural heritage / edited by A. Rubinstein, Moscow, State Institute for Art Studies, 2016. pp. 5-30.

[7] G.K. Hrupin, The reorganization of architectural science: Science center at Gosstroy of the USSR. Academy of construction and architecture of the USSR // The aesthetics of the thaw period: New in architecture, art, culture / edited by O.V. Kazakova. M.: Rosspen, 2013. p. 326 .

[8] I.A. Bondarenko, The cultic basis of the architectural culture // Southern Department of the Russian Architectural and Construction Sciences Academy and of the Rostov State University of Civil Engineering. № 19, 2015, pp. 8-19.

[9] T.F.Savarenskaya, I.A.Bondarenko, N.V.Kozhar, D.O.Shvidkovskiy, Urban art in modern time and urban planning thought in Italy, Austria and Germany. Moscow: KomKniga, 2006, pp. 7-16.

[10] V.A. Kazakova, Being of architecture as an existential problem // Problems of the theory of architecture. Architecture in dialogue with a human / compiled and edited by. I.A. Dobritsyna, Moscow: Lenand, 2013.

[11] Oswald Spengler, Der Untergang des Abendlandes. Umrisse einer Morphologie der Weltgeschichte. C.H. Beck, München, 1923.

[12] Mircea Eliade, The Sacred and the Profane: The Nature of Religion (trans. Willard R. Trask), Harper Torchbooks, New York, 1961.

[13] Y.L. Kosenkova, Soviet city in the 1940s - first half of the 1950s From creative search to the practice of building. Moscow: URSS, 2000. pp. 9-17.

[14] V.A. Ilichyov, Principles the transformation of the city // Gradostroitelstvo. Mocow, 2009, No. 3, pp. 20-30. 